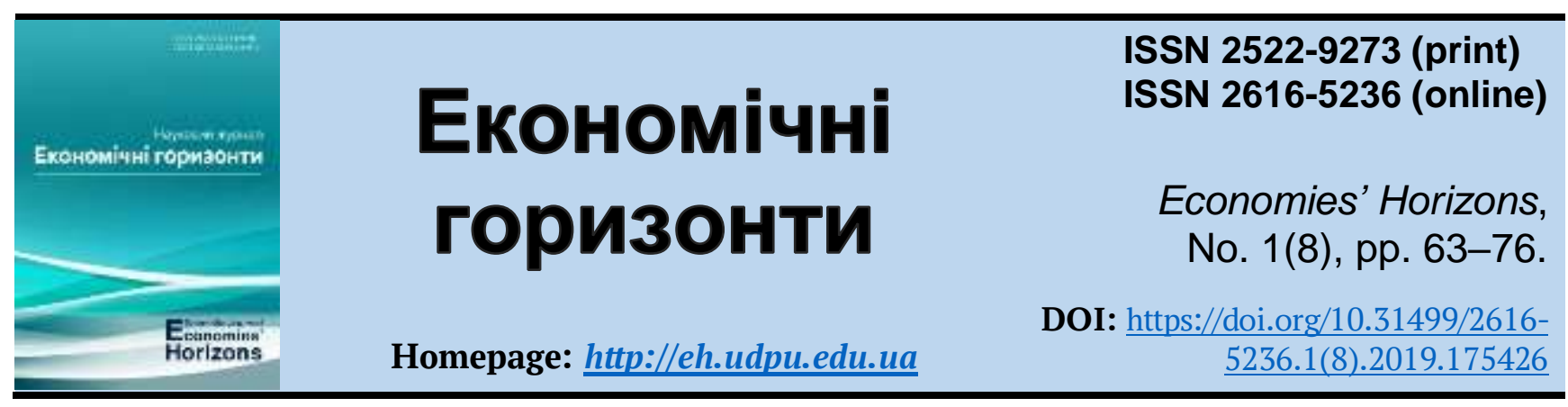

UDC 005.591.6:33

\title{
Innovative potential: research on the scientific-categorical apparatus of innovation economy
}

\author{
Maryna V. Skyba ${ }^{1}$, Cand. Sc. Pub. Adm., Associate Professor
}

Received: 14 March 2019

Accepted: 16 April 2019

\begin{abstract}
Skyba, M. V. (2019), "Innovative potential: research on the scientific-categorical apparatus of innovation economy”, Economies' Horizons, no. 1(8), pp. 63-76, doi: https://doi.org/10.31499/2616-5236.1(8).2019.175426.
\end{abstract}

Abstract. The essence of innovative potential should be investigated. The scientific sources in this field should be analysed. In such way we can improve and develop theoretical and methodological background of our scientific research. The purpose of the research is offer suggestions for improving the theoretical basis of innovation potential. Scientific approaches which used for analysis of innovation potential should be systematize. Methods. Such scientific methods as system approach, scientific abstraction, analyse, synthesis was used in the researches. Results. Author propose to improve scientific category of "innovative potential". Innovative potential is an integral element of the economic potential, a set of resources, opportunities, research results that can be used (if institutional environment and advantageous conditions exist) in the process of social production (with taking into account the intellectual product) to meet social needs, as well as contributing to the growth of the qualitative level of economic development. Author classified the main approaches to the analysed "innovation potential" are: lexical, resourceful, evolutionary, productive, synergetic method, from the scope of the use of scientific research results (fundamental, applied), by the degree (realization) - actual (achieved, realized) and perspective (vector of development). Practical meaning. The result of article can be used for prepare lection, study, methodological material economic disciplines. Prospects for further research. The role of the government in the process of formation and development of innovative potential should be investigated.

Keywords: innovation; innovation potential; state innovation policy; institutional environment.

JEL Classification: L 50, O 38, O 52.

Number of references: 33; number of tables: 1; number of figures: 2; number of formulas: $\mathbf{0 .}$

\footnotetext{
${ }^{1}$ Kyiv National University of Technology and Design; Doctoral Student; ORCID ID: https://orcid.org/0000-00032199-0237; e-mail: mvskyba@gmail.com.
} 


\title{
Інноваційний потенціал: розвиток науково-категоріального апарату інноваційної економіки
}

\author{
М. В. Скиба ${ }^{1}$, к. н. держ. упр., доцент
}

Стаття надійшла: 14.03 .2019 Стаття прийнята: 16.04.2019
Skyba, M. V. Innovative potential: research on the scientific-categorical apparatus of innovation economy. Економічні горизонти. 2019. № 1(8). C. 63-76. DOI: 10.31499/2616-5236.1(8).2019.175426.

Анотація. Дослідження інноваційної економіки, сутності та змісту інноваційного потенціалу потребує вивчення наукових джерел та розвитку теоретико-методологічної бази. Метою cmammi є дослідження теоретико-методологічних засад інноваційного потенціалу, систематизація наукових підходів до аналізу інноваційного потенціалу. Методи. У дослідженнях використовувалися методи формалізації, системного підходу, наукової абстракції. Результати. У статті автором запропоновано удосконалити наукову категорію «інноваційний потенціал». Інноваційний потенціал визначено як невід' ємний елемент економічного потенціалу, сукупність ресурсів, можливостей, результатів наукових досліджень, які, за умов сприятливого інституційного середовища, здатні взяти участь, бути задіяними у процес суспільного виробництва з метою вироблення продукту, здатного задовольнити суспільні потреби у певний період часу та у певному місці, а також сприяти зростанню якісного рівня економічного розвитку. Основними підходами до вивчення сутності «інноваційного потенціалу» та його структуризації пропонуються: лексичний, ресурсний, еволюційний, результативний, синергетичний, в залежності від сфери використання результатів наукових досліджень (фундаментальний, прикладний), за ступенем (мірою) реалізації - фактичний (досягнутий, реалізований) та перспективний (вектор розвитку). Практичне значення. Результати дослідження автора можуть бути використанні при викладанні навчальних дисциплін, розробці навчально-методичного забезпечення тощо. Перспективи подальших досліджень. Подальші наукові розробки автора будуть спрямовані на уточнення ролі держави у процесі формування та розвитку інноваційного потенціалу.

Ключові слова: інновації; інноваційний потенціал; інноваційна політика держави; інституційне середовище.

Кількість джерел: 33; кількість таблиць: 1; кількість рисунків: 2; кількість формул: 0.

\section{Introduction.}

The essence of innovative potential should be investigated. The scientific sources in this field should be analysed. In such way we can improve and develop theoretical and methodological background of our scientific research. The complexity and globalization of such problems in the economy and the preservation of a favorable environment for life requires attention to the development of new methods of social, economic and political governance (Soloviov, 2017). At the same time, it is noteworthy that these methods originate from the scientific synthesis of the results of the many millennia experience of human interaction with the environment and attempts to find opportunities to move from predominantly individual to collective intellectual activity, the core of which is institutionalized scientific, and innovative activity. In this regard, it's important to understand and analyse the social and economic basis of scientific and innovation activity.

\section{Literature review.}

The issue of innovative development of the economy was studied in the works: M. Tugan-Baranovskij (1894) research of industrial cycles and accumulation of loan

\footnotetext{
${ }^{1}$ Київський національний університет технологій та дизайну; докторант; ідентифікатор ORCID: https://orcid.org/0000-0003-2199-0237; e-mail: mvskyba@gmail.com.
} 
capital; A. Spiethoff (1902) an analysis of the relationship between the capacity of demand for capital (investment) goods and the state of technological progress. J. Schumpeter (1912) is considered the founder of the innovative paradigm of economic growth. Scientists focused on the study of new combinations of factors of production, new function of production, competition of new products or manufacturers using new technologies J. Schumpeter (1934, 1939). Among the characteristics of economic growth inherent in almost all developed countries, the Nobel Prize Winner S. Kuznets (1971; 1973) highlighted the rapid pace of structural transformation of the economy, namely the movement of labour from the industry into the service sector, the growth of medium-sized enterprises: from family and individual production to transnational corporations, etc. The scientist emphasizes the need for institutions to ensure the proper use of innovations generated by the development of human knowledge. M. Porter (1980) research on the factors of economic development (production, investment, innovation). It should be taken into consideration the industrial society played an important role in ensuring economic development, which enabled to expand production and production on an extensive basis.

In the absence of acute competition and in a relatively stable environment, this path is effective both for individual economic actors and for economic systems in general. If it has significant resource constraints, it will not be used to use resources. In this case, development takes place on an intensive basis (a method of economic growth, which involves the use of advanced scientific and technological advances to increase productivity and effectiveness of the socio-economic system. The intensive type of development is based on the application of the most effective production factors (higher qualification of the workforce, more advanced technology of production, new materials with predetermined properties, etc.) for solving the main socio-economic and environmental problems (Dudar and Melnychenko, 2008). Equally important are the works of R. Solow who proved the leading role of scientific and technological progress in the production process; E. Denison studied the process of knowledge accumulation and its role in economic growth; P. Rumeration determined the dependence of human capital and the rate of economic growth with the unchangeability of prices of new technologies, the leading role of the research sector; J. Galbraith researched corporations and their role in NTP; D. Bell analysed innovations, the third technological revolution, post-industrial society; P. Druker, researched the essence of economy, productivity of knowledge, innovations and entrepreneurship. D. Teis examined the enterprise in terms of a systematic approach emphasizes the integrity of its functioning as the only living organism P. Schoemaker, S. Heaton and D. Teece (2018) investigated the way innovative business models, dynamic capabilities and strategic leadership are interwoven to help organizations thrive in a changing, uncertain, complex and ambiguous world. U. Kaiser, H. Kongsted, and T. Ronde (2015) found a positive link between labour mobility and innovation measured as patent applications. P. Braunerhjelm, D. Ding and P. Thulin (2014) argued that the mobility of researchers has a positive and significant impact on the innovative result of all firms, as well as the fact that the effects differ between large and small firms (for small firms, interregional mobility of employees is more significant). J. Hodgson (2015) examining the conceptual framework of capitalism, states that the most important factor in the emergence of capitalism is the constitutive role of law and the state. The scholar points out that although private property and markets are central to capitalism, they depend on the development of an effective legal framework. J. Potts (2018) explores the origin of innovation through the prism of institutional economic theory. S. Shane and N. Nicolaou (2018) investigate the emergence of new institutions to finance high-tech companies. V. Heyets, V. Semynozhenko, A. Sukhorukov, L. Fedulova, A. Chukhno and many other economists are investigating various 
aspects of economic potential, innovation and innovation potential. According to $\mathrm{A}$. Chukhno, industrial production is characteristic of the industrial economy, when machines produce machines, which acquire a complementary conveyor and carry out massive and huge production. The land, capital were the main fundamental productive resources, or factors of production previously. Their interaction and the situation of the production process. In the opinion of V. Heyets (2004) the post-industrial stages of the main productive resources there is information and knowledge, as well as information and intellectual technologies, telecommunications as a result of the development of economy and society, the creation of a worldwide Internet network, confirmation of intellectual work. O. Poruchnyk (2004) believes that in the current formation of the global economic system on a post-industrial basis, economic circumstances and their international competitiveness are determined by the insufficiently substantiated intellectualization of the main factors of production and the availability of a powerful innovative potential. Intensive diffusion of knowledge, according to V. Soloviov, can lead to an unpredictable change in social mood and goal-setting. Especially great danger in the event that there is no natural nature of the accumulation of knowledge, and not the preparation of society to no alternative to its consumption. The analysis of international scientific sources made it possible to distinguish the main stages of the development of the international methodology of the OECD (as one of many international organizations monitoring the innovation potential). There are: the first - the stage of "origin", which began in 1980 and lasted until 1990; second stage (1991-1996); third stage (1997-2005); fourth stage (2005-2018); the fifth stage (has begun in 2018) (Skyba, 2017).

The analysis of scientific literature proved that the theme of innovative development of the economy does not lose relevance, but also acquires new features. In modern scientific researches innovative economy, knowledge economy, digitalization is investigated.
But, the theoretical framework has not been fully explored. Thus, refinement of certain scientific categories, namely the concept of "innovative potential" is needed.

\section{Methodology.}

The author used the universal methods of scientific research (induction and deduction), as well as the method of analysis. The classification method was used by author too.

\section{Research objectives.}

The purpose of the article is to investigate methodological foundations of innovation potential, to systematize approaches to the analysis of innovation potential and to clarify this scientific term.

\section{Results and discussions.}

First of all, the essence of concepts "potential" and "innovation" should be considered. The etymological meaning of the term "potential" comes from the Latin word "potential”, which means strength, strength, ability, ability that exists in a hidden form, and can manifest itself under certain conditions. The concept of "potential" has become widely used in the Ukrainian language and is used both literally and figuratively. Thus, the Dictionary of the Ukrainian Language (2019) treats the concept of "potential" both in direct and figurative sense.

For example, the "potential" means the energy reserve of the body located at this point of the force field (electric, magnetic, etc.). In figurative meaning, "potential" means a set of all available means, capabilities, productive forces, etc., that can be used in any industry, sector, field. The term "potential" is used frequently in phrases: "potential of global influence", "economic potential”, "educational potential", "production potential of the economy", "innovation potential", etc. Large Ukrainian Encyclopedia (2019) treats the notion of "potential" as possibilities, available forces, reserves, means that can be used to solve a task, achieve a certain goal.

The term "potential" means "hidden opportunities", which, in economic practice, satisfied work can become a reality (Kasyanova, Solokha, Moreva, Byelyakova and Balakay, 2013). In domestic economic literature, this 
term is broadly reduced in terms of capabilities, strengths, stocks and means that can be used, or as the level of power in any case of recovery, a set of tools that are necessary for any one. In the explanatory dictionary, this term refers to "hidden opportunities, means for any activity that may be manifest under certain conditions". Thus, the terms "potential”, "potential" denote the presence in any hidden possibilities that are not detected, or can operate in a particular field.

There are two "resource" positions which study the essence of innovation potential.

The first way (position) considers a potential as a set of resources without taking into account their interconnections and participation in the production process. Thus, L. Abalkin believes that the potential is a generalized, aggregate characteristic of resources. A feature of the second resource position is the interpretation of potential as a set of resources capable of producing a certain amount of material wealth. For example, E. Figurnov believes that the potential "characterizes the productive resources, quantitative and qualitative parameters that determine the maximum possibilities of society for the production of material goods at each given moment". There are approaches to potential classification:
- by degree (level) of aggregation (potential of global influence, world economy, national economies, territorial productive communities, clusters, national territorial communities, enterprises, structural units, industrial objects, individual workers);

- by branches of economic activity (agriculture, extractive and processing industry, services and services, water supply, construction, transport, temporary placement, information, finance and insurance, training, administrative services, education, health care, arts, other services, activity of households, activities of extraterritorial organizations and bodies);

- on a functional basis (production, marketing, financial, labour, scientific and technical, educational, infrastructure, export, engineering, scientific and technical, scientific research etc.);

- by resources (personnel, informational and methodological, organizational, material, technical, financial);

- from the scope of the use of research results (fundamental, applied);

- the stage (measure) of implementation (actual (achieved, realized), perspective (vector of development) (Fig. 1).

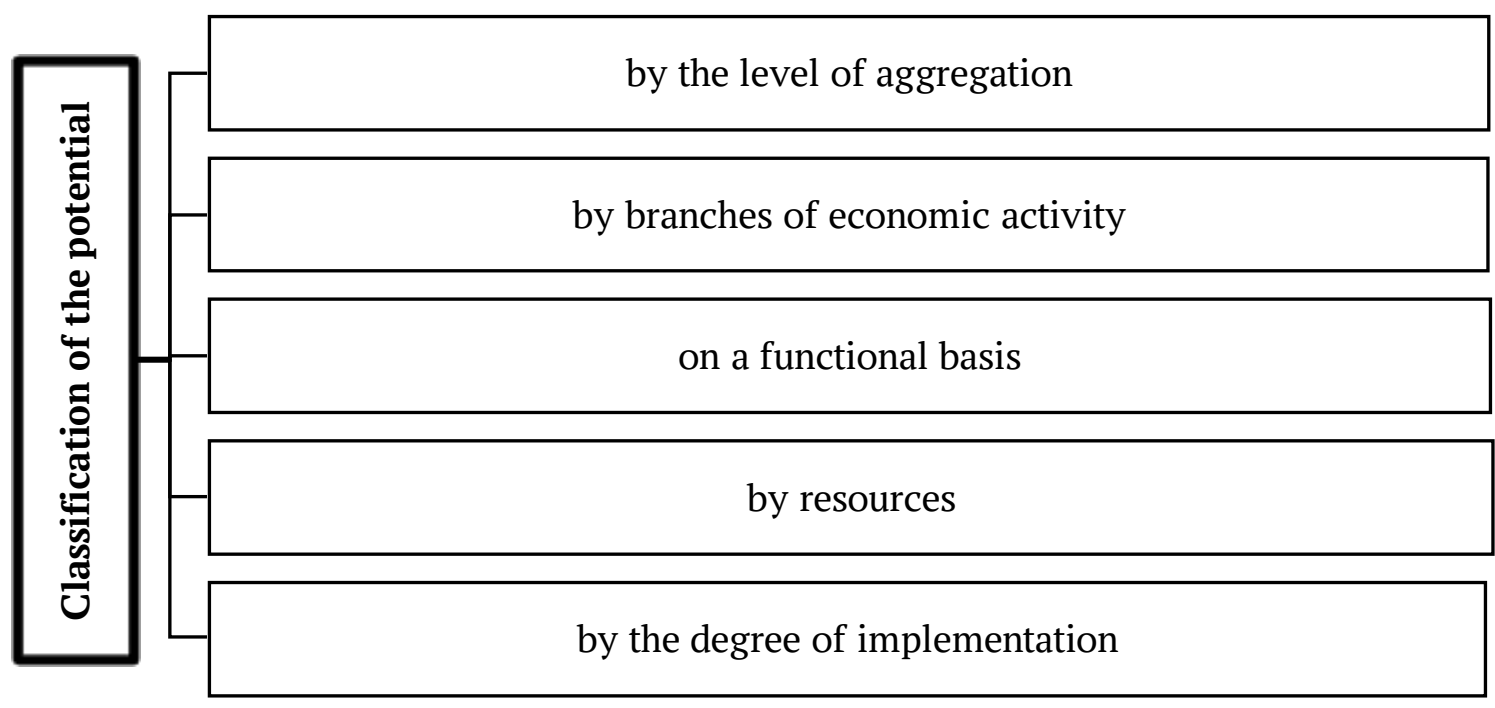

Fig. 1. Classification of the potential

Sourse: formed by (Fedulova, 2006; Dudar and Melnychenko, 2008).

Thus, in scientific sources, the concept of "potential of global influence" is defined as the possible level of influence of world processes on internal systems. In particular, the 
"potential of globalization processes" is concentrated within the state or its regions, where global influence is derived and involves determining the quantitative parameters of the internal system as a result of external influences. It forms an idea of the possible degree of interaction between the internal environment and external processes (Khvesyk, 2018).

Large Ukrainian encyclopedia interprets the "educational potential" as the ability of a social group to implement educational programs under the "scientific and technical potential" to understand the set of resources that are at the disposal of the country and serve for the implementation of scientific inventions and technical innovations, and the "productive potential of the economy" as a real volume of output that can be produced in the event of full use of resources.

The "economic potential" is the ability of the economy of the country, its branches, enterprises, farms to carry out production and economic activity, produce products, goods, services, satisfy the population, social needs, and create development of production and consumption. The Encyclopedia of Modern Ukraine (2019) considers the concept of "economic potential” as an industry, enterprise, economy, which carries out production and economic activity and includes: natural resource potential, production potential, labour potential, scientific and technical potential, export potential.

According to the opinion of Ukrainian scientists, the term "economic potential" should be considered as:

- a source of growth of national income and economic power of the country;

- the result of the development of productive forces of society;

- indicator of the maximum production capacity of the industry, enterprises, associations, resources;

- a means to meet public needs;

- the most important factor in the growth of national wealth;
- criterion of optimality of plans for the production of material goods, the use of resources and national wealth.

The analysis of scientific sources proves the lack of a single point of view regarding the interpretation of both the essence and components of the potential of the economy. For example, in the encyclopedia of modern Ukraine, the components of the potential of the economy are defined:

- natural resource potential - characterizes the natural wealth of the country already involved in economic circulation, as well as available for the development of these technologies and socio-economic relations;

- production potential - formulates material and labour resources: means of production (structures, structures, equipment), technology, workers and engineering and technical personnel;

- the volume and quality of labour potential (labour resources of the country) determines the number of active labour-intensive population, educational and professional qualification level of the latter;

- scientific and technical potential - the achievement of fundamental and applied science, discoveries and inventions, new technologies, research and experimental base, as well as scientific and technical and design personnel of the highest qualification (the main drivers of the development of the modern economy);

- export potential - determines the ability of the national economy to produce products that are competitive in world markets and to export them in sufficient quantities at world prices.

Consequently, the term "potential" has become widely used in the Ukrainian language. This notion is used both in direct and figurative meaning. It is widely used in the economic literature in the concepts of "potential of the economy", "production potential", "educational", "scientific and technical potential”, "innovation potential”, etc. The concept of potential acquires a synonymic meaning 
with words such as: ability, capabilities, resources, etc.

We found that the concept of "potential" means a certain amount of resources, stocks, opportunities that can be involved at a certain time and in a certain place in order to solve the tasks and achieve the stated goals.

The analysis of legal, economic and other scientific sources suggests the absence of a single, generally accepted notion of "innovation", and the search for a single point of view on the definition of this category has repeatedly been the subject of numerous scientific discussions. So, in 1939, the notion of "innovation" was used by Austrian economist Joseph Schumpeter in his "Business Cycles: Business $\mathrm{Cy}$ cles: A Theoretical, Historical, and Statistical Analysis of the Capitalist Process". J. Schumpeter argues that new technologies create together bunches, "clusters" of innovations, which bring to the economy the charge of technological progress and constitute the material basis of changes in the technological structure of the economy. Modern understanding of innovation is quite different from the innovations that J. Schumpeter explored. His "innovation" in the literal sense means the realization of a scientific discovery, a technical invention in a new technology or a new type of product, it is considered as a new function of production. In Modern Ukrainian Encyclopedic (2019) sources, this notion is interpreted as the result of the development and introduction of new or improved technology in the fields of economics, management, commerce, marketing or social sphere, which, when applied, gives the opportunity to obtain a comprehensive effect (economic, social, ecological, scientific and technical etc).

"Innovation" is the result of research and development that can improve the technical, economic and consumer characteristics of existing products, processes, services or become the basis for something new (Fedulova, 2006). L. Fedulova defines "innovation" as the final result of the activity on the implementation or improvement of the product being implemented in the market, new or improved technical progress, which is used in practice. Professor V. Martynenko (2003) believes that the term "innovation" should include sufficient critical mass for the general effect of the corresponding nature of the relations between people who, in the process of interconversion of resources from one form to another, lead to its increase on the basis of synergy. It also serves as a form of meeting the needs of society, which are the basis of a new cycle of expanded reproduction of GDP.

Synonymous with the concept of "innovation" are the concept of "novation", «novelty». Unlike "innovations", "novation" is a progressive novation, which is involved in dynamics, a new one for an organizational system that accepts and uses it. Despite the generality of the data, the concepts of "novation" are not only a product of activity but also a process (implementation), and "novelty" is an object of innovation, something that needs to be implemented and used. The Ukrainian legislation has consolidated the concept of "innovation" as newly created (and / or) improved competitive technologies, products or services, as well as organizational, technical, industrial, commercial, or other decisions that significantly improve the structure and quality of production and (or) social sphere.

The State Statistics Service of Ukraine (2018) understands the concept of "innovation" in the introduction of the use of any new or significantly improved product (product, service) or process, a new method of marketing or a new organizational method in the activities of the enterprise (organization), the organization of workplaces or external communications, tricks. It should be noted that the terms "innovation" and "innovation activity", enshrined in Ukrainian legislation, do not fully disclose the essence of these phenomena, lead to numerous legal conflicts and the impossibility of economic entities to act in the legal field. Therefore, it is necessary to amend the legislation, taking into account the opinion of scientists. Innovation is a new or improved technologies, types of products or services, as well as organizational and technical decisions of a 
production, administrative, commercial or other nature that improve the structure and quality of production and (or) social sphere, increase their effectiveness. Uncertainty in legislation of a multi-level nature of innovation leads to the dispersion of public funds and the impossibility of concentrating limited financial resources on basic (or basic) innovations that lead to qualitative changes in the structure of the economy, state and socio-cultural system. Therefore, it is necessary to carry out the classification of innovations by groups and to identify those that most contribute to a qualitative change in the structure of the economy.
V. Bodrov,
O. Safronova
and

N. Baldych divide innovations into the following groups: at the level of novelty (radical - the introduction of discoveries, inventions, patents, etc. - ordinary - know-how etc.); at the stage of the product life cycle, which introduces innovation (innovations in research and development, innovations in production, innovations at the stage of service); in the form of implementation (product, process); in the sphere of application (technological, production, economic, trade, social, management); at the pace of implementation (fast; slow; uniform; jump-free); by results of implementation (economic, social, environmental, integrated) (Bodrov, Safronova and Baldych, 2010).

The Oslo manual (2018) defines the concept of "innovation" as a new or improved product or process (or a combination thereof) that is significantly different from previous products or processes and which has been made available to potential users (for a product) or put into operation by an institutional unit (relative to processes).

Consequently, despite the difference in the interpretation of the concept of "innovation" in scientific sources, but the definition of "innovation" as an activity (process) or result; a common feature for them is the synthesis of functions of novelty, production implementation and use, commissioning; availability for users, consumers, market. The concepts of "educational potential", "scientific and technical potential", "innovative potential" are usually used in economic literature as synonyms. However, in our opinion, these concepts are different, because they have different functions (Table 1).

\section{Table 1. Essential description of the concepts}

\begin{tabular}{|l|l|l|}
\hline \multicolumn{1}{|c|}{$\begin{array}{c}\text { Educational } \\
\text { potential }\end{array}$} & \multicolumn{1}{c|}{$\begin{array}{c}\text { Scientific and technical } \\
\text { potential }\end{array}$} & \multicolumn{1}{c|}{ Innovative potential } \\
\hline $\begin{array}{l}\text { the ability of the so- } \\
\text { cial group to imple- } \\
\text { ment educational } \\
\text { programs }\end{array}$ & $\begin{array}{l}\text { the achievement of fundamen- } \\
\text { tal and applied science, open- } \\
\text { ness and output, new technolo- } \\
\text { gies, pilot-experimental basis, } \\
\text { as well as higher-level scien- } \\
\text { tific-technical and design per- } \\
\text { sonnel }\end{array}$ & $\begin{array}{l}\text { as the aggregate amount of resources, inven- } \\
\text { tories, facilities available at the disposal of } \\
\text { the country and can be activated at a certain } \\
\text { time and place in order to introduce novelty } \\
\text { or commissioning, as well as in production } \\
\text { or in process, to achieve a result accessible } \\
\text { to users, consumers, market }\end{array}$ \\
\hline
\end{tabular}

Sourse: formed by (Large Ukrainian Encyclopedia, 2019).

Innovation potential in our opinion should be different from the investment potential. The investment potential is based on economic potential and includes production, technical, innovation, personnel and financial and economic potential that is considered as a quantitative and qualitative characteristic and opportunities for using all kinds of resources that have their own resources for economic and social development, market potential characterizes the level of investment competition, influence of value and conditions for investment activity. Elements of investment potential serve as the use of free financial resources with the permission of their transformation into investment. Innovative potential - a set of funds that take place in the intellectual, technological, research and production resources of their 
respective infrastructures, capable of producing new knowledge, as well as an effective mechanism for commercializing the latter.

One can agree with L. Fedulova (2006), which, under the "innovative potential", understands the ability of the systemic people and promptly fix innovations in accordance with the adopted development strategies; a set of different types of resources, material, financial, intellectual, scientific and technical means for the implementation of innovation activities. A. Poruchnyk (2004) defines "innovative potential" as a set of intellectual, technological, scientific and industrial resources available in the country, with appropriate infrastructure support that can create new knowledge, as well as the effective mechanism of commercialization of the latter. The answer to the Law of Ukraine "On the Priority Directions of Innovation Activity in Ukraine" of September, 8, 2011, No. 3715-IV, “innovation potential" was recognized as a set of scientific and technological, financial, economic, industrial, social, cultural-educational opportunities of the country (industry, region, enterprises, etc.), necessary to provide innovative development of the economy.

Therefore, the innovative potential is an integral element of economic potential, a set of resources, opportunities, reserves, stocks, results of scientific research, which, in a favorable institutional environment, can participate, be involved in the process of social production in order to develop a product capable of meeting public needs at a certain period of time and in a certain place, as well as to promote the growth of a qualitative level of economic development by changing the structure of social production in the direction of increasing the share of science high-tech industries in the country's GDP.

The investigation of scientific literature allows us to classify the main approaches to the disclosure of the essence of "innovative potential”. Thus, the lexical approach is based on the search for historically fixed in the minds of people the ratio of the word to a certain phenomenon of reality, resource - focuses on an ordered set of resources that ensure the implementation of the innovative activity of the market entity. The advantages of this approach are an attempt to assess the current situation of the development of innovative processes (highlight strengths and weaknesses). The approach of "hidden reserves" differentiates resources for realized and unrealized (hidden) resources, which can be put into effect to achieve the ultimate goal of economic entities. At stage (measure) of realization - actual (achieved, realized) and perspective (vector of development). Synonymic approach identifies innovation potential with such concepts as "educational", "scientific", "scientific and technical”, “intellectual”, “creative” (Fig. 2).

Evolution defines "innovation potential" as a measure of the ability and willingness of an economic entity to innovate. Under the ability to understand the presence and balance of the structure of the components of the potential, and willingly - the adequacy of the level of development of these resources. An effective approach analyses the "output parameters" of innovation activity and reflects the final result of realization of available opportunities in the form of a new product obtained during the implementation of the innovation process.

The disadvantage of this approach is the inability to analyse the presence and balance of the structure of components of the innovation potential and the adequacy of the level of potential development for the formation of innovation activity of the economy.

Synergistic approach (a combination of resource and effective approaches) is a set of innovative resources, provided in the form of products of innovation activity, production sphere. Depending on the scope of using the results of scientific research we can determined (fundamental, applied). At stage (measure) of realization we can determined actual (achieved, realized) and perspective (vector of development). 

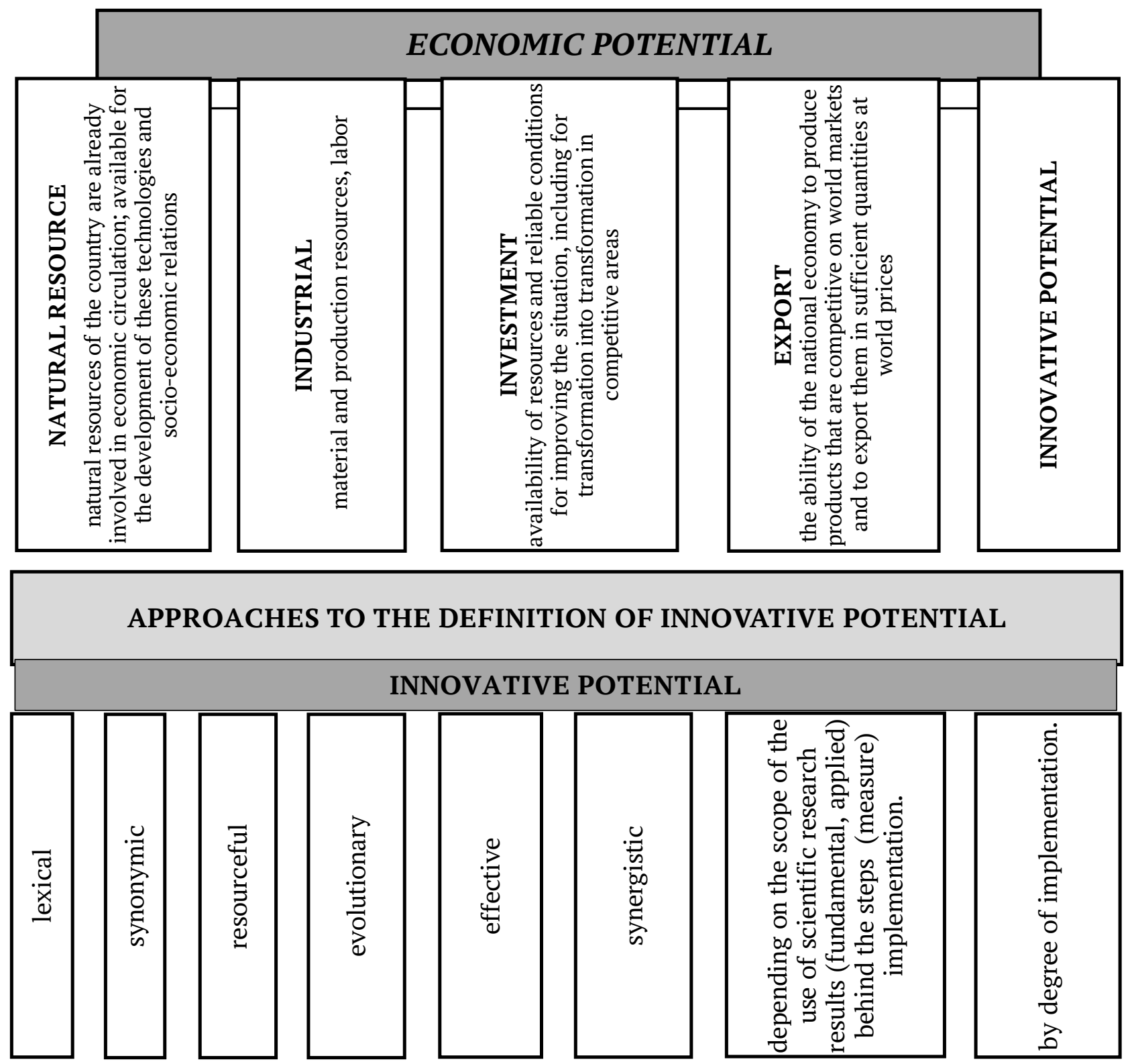

COMPOSITION OF INNOVATIVE POTENTIAL

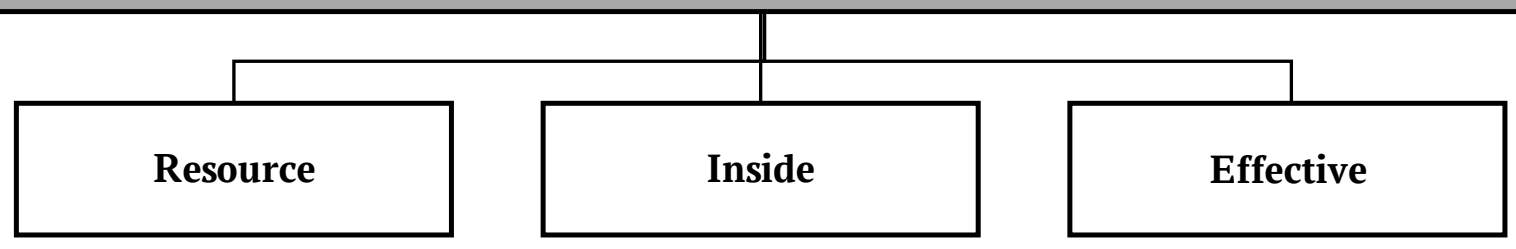

Fig. 2. Innovation potential in the structure of economic potential

Sourse: formed by (Fedulova, 2006; Dudar and Melnychenko, 2008).

Innovation potential can also be defined as the ability to change, improve, progress, and develop events. This proves such a phenomenon as diffusion of innovations. Using of new equipment (which is a concrete result of the innovation process, innovation) leads to the production of new products that enter the market and are the source of further changes. At the same time, the "effect of replicating innovations" is growing much faster than replication itself.

Innovation potential is characterized by: the ability to accumulate and develop independently. Developing innovative potential 
reveals even greater opportunities for development and is an impetus for it.

The use of structural and system approaches allows us to isolate the components of the innovative potential, namely: resource, internal, productive.

The resource component of the innovation potential depends on the possibilities of using resources in the innovation process (logistical, informational, financial, human resources, which in turn are also divided into elements that coexist in unity, direct communication and interdependence).

The internal component of the innovation potential - ensures the capacity and efficiency of the functioning of its other elements. Subjects of innovation, which provide: internal processes of innovation (invention and production of a new product); direct introduction of innovative technologies; the interaction of the object of research (enterprise) with the science that provides advanced ideas and already designed innovation, as well as the market that requires the finished product, as well as methods, means of organizing the management of the innovation process.

The effective component reflects the result of realization of the existing opportunity, that real actual innovative product obtained in the innovation process, that is, the achieved level of potential.

It is worth emphasizing once again that in today's conditions the knowledge intensity of labour is increasing (science is transformed into direct productive force), the course of the innovation process determines the tendencies of change both in the social economy and in public administration. The importance of the information component in economic and social processes is increasing (global information systems are being formed), the service sector is developing, economic activity goes beyond national economies and acquires global features. One of the main trends in the world is the formation of a "new economy" based on human intelligence, knowledge (production and use of new knowledge, turning them into a complete factor of production, which plays a leading role in the system of factors). The implementation of new knowledge, innovative processes is carried out through investments and the further exploitation of new technologies and productive assets that form their reproductive cycle, increasing national wealth (Krasnokutska, 2003).

The development of the innovative potential of the economy is provided by the appropriate level of education at the vocational schools and higher educational institutions of the I-IV levels of accreditation, centers, institutes and other organizational structures in the field of training, retraining and professional development of personnel, the performance of postgraduate and doctoral studies, the level of staffing of scientific and scientific and technical works on scientific degrees and categories of personnel, results of fundamental and applied researches and technological acquaintances. Influence on the development of innovative potential of the economy are: scientific and technical infrastructure, financial-investment, venture capital, regulatory, organizational, production-technological, informational, expert-consulting, etc.

In the opinion of scientists, each new product undergoes a certain "life" cycle, during which there are changes in the scope of its implementation and the magnitude of profit, and the duration of "life" of the product depends on its purpose and specific qualitative characteristics (Dudar and Melnychenko, 2008). The "life" cycle of innovative products includes 5 stages:

The stage of development (the origin of ideas, $\mathrm{R} \& \mathrm{D}$, the development of production technology, the product is not available on the market, only the investment of capital is available).

Introduction to the market (the establishment of a technological process, the production of a small party, the formation of a strategy and sales channels, no profit).

Stage of growth (rapid perception of a new product by the market and rapid growth of profits from its implementation). 
The maturity stage (slowing down of sales, saturation of the market, profit stabilizes or decreases due to rising costs for its protection from competitors). The "life" cycle of innovation actually ends.

The stage of decline (a sharp decline in sales and profits, the product is removed from production).

According to M. Porter (1980), most organizations systematically update the range of products and services, modernize and create new production systems, and therefore constantly initiate innovation changes.

However, not all firms are capable to create a new product, especially technically sophisticated. Therefore, some of them co-operate with others, performing only part of the work, which corresponds to one of the stages of the innovation process. So, small and medium-sized firms buy from the pioneer firms that have created a new product, a license (permission) for its manufacture and sale. However, the commercial impact of such an engagement of innovation will be significantly lower, as its utility has already been noticed by many business entities that are also joining its use. For great potential, innovation, as a rule, extends beyond the enterprise through diffusion (Latin diffusio-distribution). This is especially true for technological innovations. The spread of innovation in various sectors of the economy reflects the logistic curve (S-shaped), which simulates the transition from one relatively stable industry to another, the process of radical change that accompanies the innovative activities of industry enterprises, and reflects the stages of the life cycle of innovation: the origin, diffusion and decline.

The use of the logical-historical approach makes it possible to distinguish a person as one of the main subjects of the "innovation potential" and emphasize the importance of the role of the state in shaping the institutional environment for the development of "innovative potential" and society in exercising control over science and implementing its practical results. It should be noted that even before the first millennium $\mathrm{BC}$, the scientific worldview became quite widespread. The achievements of the philosophers of that period made it possible to comprehend the fact that it is just as necessary to see, hear, feel, and touch on the life of a person to "know". Chapter 1 of the first book of the first Aristotle "Metaphysics" begins with the phrase: "All people by their nature seek to know (knowledge)". And Aristotle further argues that the aspiration for knowledge in a person has the same origin as his desire to hear, see, feel, touch.

According to V. Soloviov (2017), not always the presence of sight will allow a person to become an artist, to distinguish the finest shades of color, and not always the presence of hearing allows a person to become an outstanding composer or musician. The desire for knowledge, which is inherent in every person, in general, allows him to become an innovator, that is, a person who, based on the accumulated knowledge, can change the "norm" of relations between man and the environment.

According to V. Soloviov (2017), there is a particularly high danger in the event that the government neglects the availability of natural properties to accumulate knowledge and does not care about preparing society for no alternative to its consumption. One can agree with the opinion of the scientist that society must perform the function of controlling the state of science and the practical use of its results. As an example of a peculiar "resistance" of society to innovation, the scientist cites the events that took place in the UK in the late XVIII and early XIX centuries (Luddites against the introduction of machinery and capitalist exploitation), emphasizing that: if the use of scientific results significantly changes technology and production process, then obstacles to the introduction of new technologies and new equipment by workers who are not inclined to change the tools of their work without understandable reasons for them.

\section{Conclusions.}

Author propose to improving scientific category of "innovative potential". Innovative potential is an integral element of the economic potential, a set of resources, 
opportunities, research results that can be used (if institutional environment and advantageous conditions exist) in the process of social production (with taking into account the intellectual product) to meet social needs, as well as contributing to the growth of the qualitative level of economic development. Author classified the main approaches to the analysed "innovation potential” are: lexical, resourceful, evolutionary, productive, synergetic method, from the scope of the use of scientific research results (fundamental, applied), by the degree (realization) - actual (achieved, realized) and perspective (vector of development).

The main approaches to the study of "innovation potential" are: lexical, resourceful, evolutionary, productive, synergetic, from the scope of the use of scientific research results (fundamental, applied), by the degree (realization) - actual (achieved, realized) and perspective (vector of development). The main features that include the modern standard of development of international innovation methodology are: the complex role of global value chains; new information technologies and their impact on new business models appeared; increase in the value of capital based on knowledge; progress in understanding innovation processes and their economic impact.

Innovative processes of digital transformation are particularly important for modern international methodologies. International methodologies in the field of innovation will not only deepen theoretical knowledge and understanding of innovation processes, but also allow the development of a methodological tool for international comparative research. The society controls the basic science and the practical application of its results (in the absence of the need for environmental properties to accumulate knowledge, rather than the preparation of society for the lack of alternative of its consumption) and it can reduce the level of danger in such a conditions.

\section{References}

Bodrov, V. H., Safronova, O. M. and Baldych, N. I. (2010), Derzhavne rehuliuvannia ekonomiky ta ekonomichna polityka [State regulation of the economy and economic policy], Akademvydav, Kyiv, Ukraine, $520 \mathrm{p}$.

Braunerhjelm, P., Ding, D. and Thulin, P. (2014), "Does labor mobility foster innovation? Evidence from Sweden“, available at: https://entreprenorskapsforum.se/wp-content/uploads/2014/12/WP 30.pdf (Accessed 10 March 2019).

Dictionary of the Ukrainian language (2019), “Potential”, available at: http://sum.in.ua/s/potencial (Accessed 10 March 2019).

Dudar, T. H. and Melnychenko, V. V. (2008), Innovatsiinyi menedzhment [Innovation management], Ekonomichna dumka, Ternopil, Ukraine, $250 \mathrm{p}$.

Fedulova, L. I. (2006), Innovatsiina ekonomika [Innovative economy], Lybid, Kyiv, Ukraine, 480 p.

Heyets, V. M. (2003), Perekhidna ekonomika [Transition Economy], Vyshcha shkola, Kyiv, Ukraine, 591 p.

Hodgson, G. (2015), Conceptualizing Capitalism: Institutions, Evolution, Future, University of Chicago Press, Chicago, USA, $456 \mathrm{p}$.

Institute of Encyclopedic Research of the National Academy of Sciences of Ukraine (2019), "Encyclopedia of Modern Ukraine”, available at: http://esu.com.ua (Accessed 10 March 2019).

Kaiser, U., Kongsted, H. C. and Ronde, T. (2015), “Does the mobility of R\&D labor increase innovation?”, Journal of Economic Behavior \& Organization, vol. 110, pp. 91-105, doi: https://doi.org/10.1016/j.jebo.2014.12.012.

Kasyanova, N. V., Solokha, D. V., Moreva, V. V., Byelyakova, O. V. and Balakay, O. B. (2013), Potentsial pidpryiemstva: formuvannia ta vykorystannia [Potential of the enterprise: formation and use], Tsyfrova typohrafiia, Donetsk, Ukraine, $257 \mathrm{p}$.

Khvesyk, M. A. (ed.) (2018), Ekonomika pryrodokorystuvannia: hlosarii osnovnykh terminiv [Environmental economics: a glossary of basic terms], Derzhavna ustanova "Instytut ekonomiky pryrodokorystuvannia ta staloho rozvytku Natsionalnoi akademii nauk Ukrainy”, Kyiv, Ukraine, 94 p.

Krasnokutska, N. V. (2003), Innovatsiinyi menedzhment [Innovation management], KNEU, Kyiv, Ukraine, 504 p. Kuznets, S. (1971), "Lecture to the memory of Alfred Nobel", available at: https://www.nobelprize.org/prizes/economic-sciences/1971/kuznets/facts/ (Accessed 10 March 2019). 
Kuznets, S. (1973), "Modern economic growth: findings and reflections", The American Economic Review, vol. 63, no. 3, pp. 247-258.

Martynenko, V. F. (2003), "Formation of innovation process in Ukraine: methodological aspect", Visnik UADU, no. 2, pp. 84-91.

Nosova, O. V. (ed.) (2013), Natsionalna ekonomika [National Economy], Tsentr uchbovoi literatury, Kyiv, Ukraine, $512 \mathrm{p}$.

OECD/Eurostat (2018), Oslo Manual 2018: Guidelines for Collecting, Reporting and Using Data on Innovation, 4th Edition, The Measurement of Scientific, Technological and Innovation Activities, OECD Publishing, Paris/Eurostat, Luxembourg, doi: https://doi.org/10.1787/9789264304604-en.

Porter, M. E. (1980), Competitive strategy: Techniques for analyzing industries and competitors, The Free Press, New York, USA, $397 \mathrm{p}$.

Poruchnyk, A. M. (2014), “The innovation potential of Ukraine and its implementation in international scientific and technical cooperation", The Journal of International Economic Policy, vol. 1, pp. 94-121.

Potts, J. (2018), "Governing the innovation commons", Journal of Institutional Economics, vol. 14, special issue 6 (Special issue on innovation and institutions from the bottom up), pp. 1025-1047, doi: https://doi.org/10.1017/S1744137417000479.

Schoemaker, P., Heaton, S. and Teece, D. (2018), “Innovation, dynamic capabilities and leadership”, California Management Review, vol. 61, issue 1, pp. 15-42, doi: https://doi.org/10.1177/0008125618790246.

Schumpeter, J. A. (1912), Theorie der wirtschaftlichen Entwicklung, Duncker \& Humblot, Leipzig, Germany.

Schumpeter, J. A. (1934), The Theory of Economic Development: An Inquiry into Profits, Capital, Credit, Interest and the Business Cycle, Harvard University Press, Cambridge, UK.

Schumpeter, J. A. (1939), Business Cycles: A Theoretical, Historical and Statistical Analysis of the Capitalist Process, McGraw-Hill, New York, USA.

The State Statistics Service of Ukraine (2018), Naukova ta innovatsiina diialnist Ukrainy u 2017 [Scientific and innovation activity of Ukraine in 2017], Kyiv, Ukraine, 178 p.

Shane, S. and Nicolaou, N. (2018), "Exploring the changing institutions of early-stage finance", Journal of Institutional Economics, vol. 14, special issue 6 (Special issue on innovation and institutions from the bottom up), pp. 1121-1137, doi: https://doi.org/10.1017/S1744137417000467.

Skyba, M. V. (2017), "The influence of the state on improving the institutional environment in the process of innovative-structural changes in the economy: a theoretical aspect", Ekonomika ta derzhava, no. 6, pp. 3438.

Soloviov, V. P. (2017), "Science and innovations as tools of technological and social evolution”, Problemy i perspektyvy innovatsiinoho rozvytku ekonomiky $v$ konteksti intehratsii Ukrainy $v$ Yevropeiskyi naukovo-innovatsiinyi prostir [Problems and prospects of innovation development of the economy in the context of Ukraine's integration into the European scientific and innovation space], Materialy XIII Mizhnarodnoi naukovo-praktychnoi konferentsii [Materials of the XIII International Scientific and Practical Conference], Odesa, Ukraine, September 11-13, 2017, pp. 412-422.

Spiethoff, A. (1902), "Vorbemerkungen zu einer Theorie der Überproduktion", Jahrbuch fur Gesetzgebung, Verwaltung und Volkswirtschaft im Deutschen Reich, vol. 26, pp. 721-759.

State Scientific Institution "Encyclopedic Publishing House” (2019), "Large Ukrainian Encyclopedia”, available at: https://vue.gov.ua (Accessed 10 March 2019).

Teece, D. (2018), “Dynamic capabilities as (workable) management systems theory”, Journal of Management \& Organization, vol. 24, no. 3, pp. 359-368, doi: https://doi.org/10.1017/jmo.2017.75.

The Verkhovna Rada of Ukraine (2012), The Law of Ukraine "On the Priority Directions of Innovation Activity in Ukraine”, available at: https://zakon.rada.gov.ua/laws/show/3715-17 (Accessed 10 March 2019).

Tugan-Baranovskij, M. I. (2004), Promyshlennye krizisy. Ocherk iz social'noj istorii Anglii [Industrial crises. Essay on social history of England], Naukova dumka, Kyiv, Ukraine, 368 p.

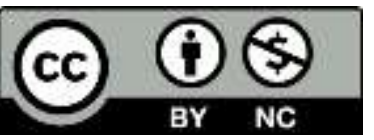

Цей твір ліцензовано на умовах Ліцензії Creative Commons «/з Зазначенням Авторства - Некомериійна 4.0 Міжнародна» (CC BY-NC 4.0). This is an open access journal and all published articles are licensed under a Creative Commons "Attribution-NonCommercial 4.0 International" (CC BY-NC 4.0). 